DOI 10.37882/2223-2982.2020.12-2.15

\title{
НАКОПЛЕНИЕ СИМВОЛИЧЕСКОГО КАПИТАЛА П.П. БАТОЛИНЫМ В СРЕДЕ ЗАПАДНОЙ ДЕЛОВОЙ эЛИТЫ В 1917-1919 ГГ.
}

\section{THE ACCUMULATION OF SYMBOLIC CAPITAL BY PROKOPIY BATOLIN IN THE ENVIRONMENT OF THE WESTERN BUSINESS ELITE IN 1917 - 1919}

E. Kashapova

Summary: The article reflects the business dealings and commercial plans of the financier, entrepreneur and co-owner of the trade and industrial partnership «Stakheev \& Co» Prokopiy Batolin (1878-1939) during his trip to the United States of America in 1918-1919 and the previous negotiations. Using the biographical method of research and the volume of aggregate information about Batolin's economic, political and social connections, the author attempts to reconstruct historical events that influenced the economic and political plans of the Russian and Western financial elite.

In the reconstruction of personal biography the author used documents and materials from Russian and foreign archives and libraries: State Archive of the Russian Federation, Foreign Policy Archive of the Russian Federation, Central State Historical Archive of St. Petersburg, State Archive of Khabarovsk Region, the archives of the Michigan and California universities' libraries.

The meetings and negotiations reflected in the article for the most part did not affect the formation of Batolin's economic capital, but the environment presented: Edward M. House, Louis Dembitz Brandeis, Robert Rutherford «Colonel» McCormick, Alexander Legge became the basis for the conditional and symbolic capital of Prokopiy Batolin.

Keywords: financial elite, USA, economy, Stakheev, Batolin, symbolic capital, personal biography.

\author{
Кашапова Екатерина Александровна \\ заведующая музеем истории города, Елабужский \\ государственный музей-заповедник; аспирант, \\ Елабужский институт (филиал) \\ Казанского федерального университета \\ katya83@list.ru
}

Аннотация: В статье отражены деловые связи и коммерческие планы финансиста, предпринимателя и совладельца Торгово-промышленного товарищества «И. Стахеев и К» Прокопия Петровича Батолина (1878-1939) во время его поездки в Соединенные Штаты Америки в 1918-1919 гг. и предшествующие ей переговоры. Используя биографический метод исследования и объем совокупной информации об экономических, политических и социальных связях П.П. Батолина, автор предпринимает попытку реконструировать исторические события, оказавшие влияние на экономические и политические планы российской и западной финансовой элиты.

В рамках реконструкции персональной биографии были использованы документы и материалы российских и зарубежных архивов и библиотек: Государственного архива Российской Федерации, Архива внешней политики Российской Федерации, Центрального государственного исторического архива СПб, Государственного архива Хабаровского края, архивы библиотек Мичиганского и Калифорнийского университетов.

Отраженные в статье встречи и переговоры большей частью не повлияли на формирование экономического капитала П.П. Батолина, а представленное окружение: Э.М Хаус, Л. Брандейс, Р. Маккормик, А. Легге, К.М. Вулли стали основой для условного и символического капитала Прокопия Батолина.

Ключевые слова: финансовая элита, США, экономика, Стахеев, Батолин, символический капитал, персональная биография.

йна и территориальный и финансовый передел мира по итогам Первой мировой войны, выпали на короткий временной период. Историческое время в хронологическом отрезке 1917-1919 гг. имеет высокую плотность, в связи с чем насыщенной событиями оказывается не только социальная история, но и персональная история.

Цель данной статьи - реконструировать персональную биографию П.П. Батолина в 1917-1919 гг. и очертить круг социальных и политических связей выдающегося предпринимателя и финансиста, как основной критерий бизнес-статуса П.П. Батолина в среде западной деловой элиты, тем самым детализировать общеисторические события.

Великая российская революция, Гражданская во- 
Прокопий Петрович Батолин (1878-1939) - выходец из государственных крестьян Елабужского уезда, начал карьеру предпринимателя с приказчика по хлебному делу в Торговом доме И.Г. Стахеева в г. Елабуге Вятской губернии, а затем был переведен главой фирмы в г. Санкт-Петербург. В 1912 году совместно с И.И. Стахеевым на правах половинного владельца организовал Торгово-промышленное товарищество «И. Стахеев и К». Фирма использовала банковские капиталы РусскоАзиатского банка и переросла в одно из крупнейших в мире монополистических объединений, получившее в отечественной историографии название Стахеев-Путилов-Батолин. К 1917 году Товарищество «И. Стахеев и К» обладало контрольными пакетами акций Русско-Азиатского банка, Петроградского международного коммерческого банка, Соединенного банка, Волго-Камского коммерческого банка и Бухарского банка; торгово-промышленными предприятиями в сфере железнодорожной, горнозаводской, текстильной, нефтяной, лесной промышленности, а также имело в распоряжении хлебное, страховое, печатное и газетное дело. Общий капитал активов превышал 5000000000 (пять миллиардов) золотых рублей [7, л.12], чистая прибыль, по словам П.П. Батолина, на 1917 год составила 10 (десять) миллионов долларов. [10, с.79]

Принято считать, что в период Великой российской революции, Гражданской войны, становления Советской власти, а впоследствии и введения декретов о национализации российское предпринимательство если не прекратило в корне свое существование, то деятельность приостановило. Предпринимательская деятельность купцов, банкиров, промышленников, как правило, рассматривается отечественными исследователями до 1918 г. [11, с.172] Между тем в самой истории не было четкой границы, определенной даты, после которой «все рухнуло», неоднократно современники подчеркивали тот факт, что уверенность в том, что в самом ближайшем будущем все вернется на круги своя, была настолько крепка, что в этом смогли убедить не только российскую общественность, но и зарубежную. [13, с. 56]

В этот момент Россия, раздираемая внутренними противоречиями, одновременно продолжая вести борьбу на внешней арене, представляла собой территорию и ресурсы, которые можно было как поделить заново, так и использовать не охваченные ранее: речь в первую очередь о Сахалине и сибирских землях. Сибирь представлялась иностранцам не иначе как terra incognita. На фоне прекращения российско-германских торговых отношений распространить свое экономическое влияние на новые регионы стремилась не только Европа, но и Америка, интерес к России со стороны западного партнера начинает возрастать с геометрической прогрессией. [5, с. 367]
Торгово-промышленная и финансовая группа Стахеев - Путилов - Батолин использовала период весны - лета 1917 г. как время расширения сфер влияния и закрепления позиций на уже работающих площадках по хлебу, углю и железной дороге.[14, л.31-32] Начиная с 1914 г. , деятельность Товарищества «И. Стахеев и К» была направлена на поиски новых партнеров на западе (Америка) и востоке (Япония) в обход стран Тройственного союза.[5, с. 367]

В игру на экономической мировой арене вступали не только многомиллионные капиталы держав, крупных синдикатов и отдельных финансистов, но и капиталы символические. В этот сложный период политические и экономические мировые лидеры стремились мобилизовать разнообразные ресурсы, которые могли ускорить и облегчить социальный обмен. Обладание выгодными связями, эрудиция, уровень образования, репутация, внешний вид, навыки речи, признаки высокого социального статуса, власть и престиж могли сыграть роль и перерасти из капитала символического в реальный - экономический, с возможностью обратной конвертации.

Летом 1918 г. известный банкир А.И. Путилов (РусскоАзиатский банк) и к тому времени зарекомендовавший себя в западных финансовых кругах предприниматель П.П. Батолин пароходом прибыли в г. Сан-Франциско (США). Эта поездка стала своеобразным итогом в череде финансовых переговоров на российской территории, которые велись с весны 1917 года между Товариществом «И. Стахеев и К» и крупными американскими компаниями. Помимо экономической выгоды поездка подразумевала возможность политической опоры на американский капитал. [5, с. 367] Еще летом 1917 г. при правлении Л.Г. Корнилова, а затем и весной 1918 г. при Д.Л. Хорвате и создании правления КВЖД неоднократно рассматривалось вхождение А.И. Путилова и П.П. Батолина в круг правящей верхушки предполагаемого капиталистического государства как министра финансов и министра продовольствия соответственно. [9, с. 80-87]

Знакомства и встречи П.П. Батолина во время его деловой поездки в 1918-1919 гг. в Соединенные Штаты Америки можно условно поделить на две группы, которые вели к формированию политического и экономического капитала. [12, с. 208]

В начале лета 1917 г. состоялось знакомство Прокопия Петровича Батолина и Сэмюэля Харпера (18821943) - американского ученого, специалиста по России, профессора Чикагского университета.[4, л.43-44] Сэмюэль Харпер оказывал влияние на всю политику президента Вильсона относительно России.[8, с. 170] Это знакомство сыграло ведущую роль во время пребывания П.П. Батолина летом 1918 г. в Америке и стало основой 
в формировании его политического капитала. Именно С. Харпер выступил инициатором встречи Батолина с полковником Хаусом (Эдвард Мандел Хауз (1858-1938), советник президента Вудро Вильсона) и судьей Л.Д. Брандейсом(1856-1941). С. Харпер в течение августа месяца сопровождал П.П. Батолина, являясь куратором, а в некоторых случаях выступая переводчиком. В своих мемуарах Харпер представляет реакцию Хауса на встречу с П.П. Батолиным: «...После того, как я сказал полковнику Хаусу, что, по моему мнению, у меня есть что-то, что может помочь в ситуации с Россией, и кратко описал свой "образец", мне было велено привести его». Полковник Хаус предполагал, что через Батолина можно найти новый подход к «русской проблеме», поскольку многие торговые и политические вопросы оставались нерешенными, было решено провести переговоры с членами кабинета президента в обход президента Уилсона. [1, с. 209]

Несмотря на возможность встречи с президентом Вильсоном, Прокопий Петрович не стремился реализовать ее до тех пор, пока ситуация в России не прояснится до такой степени, что «он сможет сделать конкретное предложение о том, как лучше всего развивать отношения между американским и российским народом».

Сэмюэль Харпер предложил встретиться с судьей Л.Д. Брандейсом, Батолин хорошо понимал политическую конъюнктуру и даже шутил по данному поводу, отмечая, что Брандейс «имеет левое ухо президента», в то время как полковник Хаус «имеет правое ухо»; и отмечал, что, по его мнению, левое ухо президента слышит лучше. [1, с. 210]

Самюэль Харпер оценивал встречу Батолин - Брандейс как одну из самых удачных. Судья со своей стороны также дал позитивную оценку этой беседе. П.П. Батолин же, наоборот, считал, что переговоры были неудачными, и обвинял судью в нечестности. Батолин умышленно завел разговор о негативной роли евреев в судьбе русского и американского народов. Л. Брандейс, являясь евреем, не противоречил, из чего Прокопий Петрович заключил, что он «не был ни честным евреем, ни честным американцем». В дальнейшем именно эта беседа послужит поводом для обвинения П.П. Батолина в антисемитизме. [3, с. 279]

В контексте двух основных правительственных встреч П.П. Батолин также осуществил встречи и переговоры с госсекретарями Хьюстоном, Лейном и Лэнсингом. Сайрус Х. Маккормик-младший уговаривал Батолина принять участие в Мирной конференции в Париже, но присутствие там как «неофициального» представителя и наблюдателя не вызывало у П.П. Батолина интереса.
Безусловно, нетворкинг П.П. Батолина не имел четкого разграничения на политику и экономику; как отмечает С. Харпер, в перерывах между правительственными встречами Батолин вел переговоры со многими ведущими бизнесменами: генеральным директором International Harvester Александром Легге, и медиамагнатом Робертом Маккормиком, Даже Джон Д. Рокфеллер-старший выразил желание увидеть Батолина. [1, С. 211]

Многие встречи и договоренности стали результатом переговоров с Б. Бруксом и Р. Пиккелом годом ранее в Петрограде. Байрон Брукс, являясь представителем ньюйоркской машиностроительной компании «Джеффри мануфакчеринг компании» (The Jeffrey Manufacturing Company) в Петрограде, фактически являлся крупнейшим промоутером различных компаний и представлял целую группу американских предприятий: The Armour Grain Co, Grain Co, Allied Contracting Co, Foundation Co и др., в том числе и в переговорах с «И. Стахеев и К». $[14$, л. 31-32]

Основной темой экономических переговоров и фактически вопросом решенным были дела, связанные с хлебной торговлей. П.П. Батолина впечатлял размах продовольственной компании Armour and Company (в первую очередь Armour Grain Co - отделение фирмы в области торговли хлебом, - прим. ЕК). Предполагаемое сотрудничество должно было охватывать всю Россию, максимально вовлекая регионы, связанные между собой сетью железных дорог.

В Америке П.П. Батолину предстояла встреча с директором «Сити банк» (City Bank of NY) Самюэлем MaкРобертсом, на руках у Прокопия Петровича находилось рекомендательное письмо от инженера Джона Ф. Стивенса, которое являлось своеобразным гарантом, предстояло решение вопросов в области финансирования хлебной торговли и элеваторного дела.[6, л.7-8] Также состоялась встреча с Кларенсом М. Вулли - президентом Американской радиаторной компании (American Radiator Company) и председателем Военного торгового совета. [1, с.211]

К сожалению, пока не выясненными остаются факты заключения договоров по итогам этих многочисленных встреч. Самыми результативными и широко известными на сегодняшний день в отечественной историографии являются переговоры П.П. Батолина с Генри Фордом, итогом которых стало заключение весной 1919 г. договора между «И. Стахеев и К» и «Ford Motor Company» на поставку автомобилей марки «Model T» в Советскую Россию. [15, с.334]

Впрочем, как отмечали современники, П.П. Батолину 
был важен не конечный результат тех или иных действий, а сам процесс, который так или иначе способствовал накоплению символического капитала. По всей видимости, обозначенные встречи и переговоры так и остались в планах. В 1922 году посол США в Германии А.Б. Хоутон телеграфировал госсекретарю США Ч.Э. Хьюзу, что П.П. Батолин надеется на возвращение в Россию и в инвестициях рекомендует придерживаться политики ожидания, так как Советское правительство все еще находится в процессе формирования, и что в России нет никакой реальной безопасности для капиталовложения. [2, с. 828]

Период деятельности П.П. Батолина в 1917-1919 гг. нельзя обозначить как период только предпринимательской деятельности, поскольку эти отношения и контакты имеют больше дипломатическую и политическую направленность в формате экономических отношений. Финансовая группа Стахеев - Путилов - Батолин постаралась извлечь максимум возможностей из меняющейся геополитической ситуации в мире, связав основные планы с западными партнерами. Представленный в статье список состоявшихся встреч только очерчивает круг вопросов для дальнейшего исследования влияния П.П. Батолина на экономическую и политическую парадигму российско-американских отношений.

\section{ЛИТЕРАТУРА}

1. Harper S.N. and Harper P.V. and Thompson R.B, The Russia I Believe In: The Memoirs of Samuel N. Harper, 1902-1941, Copyright 1945 by The University of Chicago. Published 1945. Composed and printed by the University of Chicago Press, Chicago, Illinois, U.S.A. P. 279

2. Papers Relating to the Foreign Relations of the United States 1922 //Volume II United States Government Printing Office Washington: 1938 P. 1042

3. Zosa Szajkowski Jews, wars, and communism, Ktav Pub. House, 1972 p 714

4. Архив внешней политики Российской Федерации (АВП РФ) Ф. 0129. оп. 17. п. 129. д. 342. л. 43—44

5. Ганелин Р.Ш. Россия и США 1914-1917 Очерки истории русско-американских отношений «Наука»-Л.: 1969 - 420 с.

6. Государственный архив Российской Федерации (ГА РФ) Ф. Р-5881 Краткие биографические сведения о П.П. Батолине. оп.1, д. 5. л.19.

7. Государственный архив Хабаровского края (ГА ХК), ф. Р-830, оп. 3, д. 3196, л.27.

8. Дэвис Д.Э., Трани Ю.П. Первая холодная война. Наследие Вудро Вильсона в советско-американских отношениях. / Пер. с англ. Е.В. Нетесовой. -М.: ОЛМА-ПРЕСС, 2002. С.480

9. Кашапова Е.А. Контекстуальная биография П.П. Батолина в архивных документах и материалах (1878-1918) // Гасырлар авазы - Эхо веков. - 2018. - № 4. - C. 80-87.

10. Кашапова Е.А. Предпринимательская деятельность П.П. Батолина в России и за рубежом в первой трети XX века. Российская провинция как социокультурное поле формирования гражданской и национальной идентичности: Сб. науч. ст.: Материалы VIII Международных Стахеевских чтений, Елабуга, 16-17 ноября 2017 г. // Сост. И.В. Маслова, И.Е. Крапоткина, Г.В. Бурдина. Елабуга, 2017. С. 78-83.

11. Очерки истории российских фирм: вопросы собственности, управления, хозяйствования / Барышников М.Н., Гессен В.Ю., Дмитриев А.Л., Китанина Т.М., Семенов А.А.; под ред. Дмитриева А.Л., Семенова А.А. - СПб.: Изд-во «Высшая школа менеджмента»; Издат. дом С.-Петерб. гос. Ун-та, 2007. -718 с.

12. П. Бурдьё. Политическое представление. Элементы теории политического поля / пер с фр.; сост., общ. Ред и предисл. H.A. Шматко. - M.: Sociol-Logos. 1993.- 336 с.

13. Совершенно лично и доверительно! Б.А. Бахметев-В.А. Маклаков. Переписка. 1919-1951. В 3-х томах. Том 1. Август 1919 - сентябрь 1921 / Под ред. 0. Будницкого. -М.: «Российская политическая энциклопедия» (РОССПЭН), 2001. - 568 с.

14. Центральный государственный архив Санкт-Петербурга (ЦГИА СПб) Ф.2178, оп.1, д.1, 1916 -1917 гг. л.120

15. Шпотов Б.М. Генри Форд: жизнь и бизнес. -М.: КДУ, 2005. - 384 с. 